\title{
Pendampingan Dan Pelatihan Desain Grafis Untuk Kewirausahaan Bagi Siswa SMK Muhammadiyah 9 Wagir
}

\author{
Arif Hidayatul Khusna dan Mayang Dintarini \\ Prodi Pend Matematika, Univ. Muhammadiyah Malang, Jl. Raya Tlogomas, Malang \\ E-mail: mayangdintarini@umm.ac.id
}

\begin{abstract}
Abstrak - Terdapat tiga tahapan wirausahan yang diajarkan di sekolah. Ketiga tahapan tersebut yaitu pra produksi, produksi, kemudian pemasaran. Masalah yang dihadapi siswa adalah pada tahap produksi yaitu permasalahan pelabelan produk. Sampai saat ini pelabelan dilakukan dengan sederhana atau bahkan tanpa pelabelan. Jika siswa dapat mendesain sendiri label produknya, tentunya hal ini akan menambah nilai jual produk. Adanya label dan brosur juga menambah nilai promosi produk siswa. Tujuan kegiatan pendampingan ini adalah memberikan pelatihan dan pendampingan desain grafis pada siswa SMK Muhammadiyah. Tahap pelaksanaan pengabdian masyarakat ini yaitu observasi, sosialisasi, pelatihan desain grafis, pendampingan pembuatan label dan brosur produk wirausaha siswa, serta evaluasi dan refleksi kegiatan pengabdian. Hasil dari kegiatan pengabdian ini berupa pelatihan dan pendampingan desain grafis bagi siswa. Semua kegiatan yang direncanakan dapat terlaksana dengan lancar, ditandai dengan keenam siswa mengikuti pelatihan dan pendampingan selama tiga hari. Selain itu terdapat tanggapan positif dari guru serta siswa yang berdampak pada berhasilnya pelatihan dan pendampingan desain grafis ini. Hal ini terlihat dari hasil desain siswa yang menarik dan dapat dijadikan sebagai salah satu alat komersil.
\end{abstract}

Kata Kunci — pendampingan, pelatihan, desain grafis, kewirausahaan

\begin{abstract}
The problem faced by students is at the production stage, namely the problem of product labeling. Until now labeling was done simply or without labeling. If students can design their own product labels, of course this will add to the selling value of the product. The existence of labels and brochures also add value to the promotion of student products. The aim of this mentoring activity is to provide training and graphic design assistance to students of SMK. The steps of this community service activities are observations, socialization, graphic design training, assistance in making labels and brochures for student entrepreneurial products, as well as evaluating and reflecting on service activities. The result of this service activity was in the form of training and graphic design assistance for students. All of the activities was well done . This can be seen from the number of students who participated in training and mentoring for three days. In addition, there are positive responses from teachers and students that have an impact on the success of this graphic design training and assistance. This can be seen from the results of student designs that are attractive and can be used as a commercial tool.
\end{abstract}

Keywords - mentoring, training, graphic design, entrepreneurship

\section{PENDAHULUAN}

Salah satu yang menjadi perhatian Kementrian Pendidikan dan Kebudayaan adalah mengembangkan pembelajaran yang dapat diaplikasikan pada era industri 4.0. Era industri 4.0 menuntut adanya generasi yang produktif dan berkarakter. Salah satu strategi yang tepat untuk menyiapkan hal itu adalah pengembangan minat wirausaha bagi siswa Sekolah Menengah kejuruan (SMK) [1]. Siswa yang memiliki minat wirausaha tinggi akan mencetak seorang wirausahawan yang handal dan bermanfaat bagi sekitar. Wirausahawan yang tercetak harus siap dalam berbagai situasi [2]. Proses pembentukan sikap kewirausahaan ini dapat melalui pelatihan dan pendampingan kewirausahaan [3].

Universitas Muhammadiyah Malang (UMM) memiliki beberapa sekolah binaan. Salah satu sekolah binaan UMM adalah SMK Muhammadiyah 9 Wagir.
Jarak UMM dengan SMK Muhammdiyah 9 Wagir adalah 18 kilometer. Lokasi sekolah ini berada pada sekitar 250 meter dari jalan raya Pandansari, tepatnya di Desa Pandanrejo, Wagir, Kabupaten Malang. Bangunan sekolah ini sebelumnya merupakan rumah wakaf. Bangunan sekolah terdiri dari gedung utama dan gedung baru. Diantara keduanya terdapat makam keluarga yang merupakan makam pemberi wakaf. Sekolah ini memiliki dua ruang kelas, satu ruang perpustakaan kecil sekaligus untuk menyimpan peralatan sekolah, satu ruang laboratorium komputer yang terdiri dari 12 unit komputer, serta satu ruang untuk ruang guru dan ruang kepala sekolah. Secara keseluruhan pegawai SMK Muhammadiyah 9 Wagir berjumlah 18 orang yang terdiri dari satu kepala sekolah, 16 guru mata pelajaran, dan satu orang karyawan tata usaha. SMK ini memiliki memiliki dua jurusan keahlian yaitu jurusan tata boga dan jurusan 
Teknik Komputer dan Jaringan (TKJ). Jurusan tata boga untuk kelas 10 terdiri dari 7 siswi dan untuk jurusan TKJ kelas 10 terdapat 4 siswa, kelas 11 terdapat 11 siswa, dan kelas 12 terdiri dari 13 siswa. Total siswa di SMK Muhammadiyah 9 Wagir adalah 35 siswa.

Pelatihan kewirausahaan di sekolah ini dapat dikatakan baik. Setiap akhir tahun setiap siswa di wajibkan menghasilkan suatu produk untuk dikomersilkan [4], [5]. Sampai saat ini produk siswa yang sudah berjalan adalah berupa keripik singkong.

Tahapan wirausaha yang diajarkan adalah pra produksi, produksi, kemudian pemasaran. Pada tahap produksi masalah yang dihadapi siswa adalah pelabelan produk. Sampai saat ini pelabelan dilakukan dengan sederhana atau bahkan tanpa pelabelan. Pada tahap pemasaran siswa terkendala dengan pembuatan desain brosur untuk promosi produk. Jika siswa dapat mendesain sendiri label dan brosur produknya, tentunya hal ini akan menambah nilai jual produk. Adanya label dan brosur juga menambah nilai promosi produk siswa. Berdasarkan pemaparan permasalahan di atas, untuk membantu meningkatkan kualitas di bidang pendidikan diperlukan kegiatan pendampingan dan pelatihan desain grafis untuk kewirausahaan bagi siswa SMK Muhammadiyah 9 Wagir.

\section{METODE}

Metode pelaksaaan dari kegiatan pelatihan dan pendampingan Desain Grafis untuk mendukung kegiatan kewirausahaan siswa SMK Muhammadiyah 9 Wagir terdiri dari lima tahapan yaitu persiapan, sosialisasi, pelatihan serta pendampingan desain grafis, dan evaluasi kegiatan.

Tahap persiapan dilakukan dengan cara observasi dan wawancara dengan pihak sekolah. Hal ini bertujuan untuk mengetahui sejauh mana kegiatan kewirausahaan di SMK Muhammadiyah 9 Wagir. Setelah observasi dan wawancara, tim pengabdian melakukan diskusi internal dan mengkaji literatur guna membahas solusi yang dapat digunakan untuk membantu permasalahan yang ada di sekolah. Tindak lanjut dari kegiatan diskusi ini adalah pembuatan jadwal kegiatan pelatihan dan pendampingan bagi siswa.

Kegiatan selanjutnya adalah kegiatan sosialisasi terkait jadwal kegiatan, materi pelatihan serta capaian kegiatan. Kegiatan sosialisasi ini melibatkan Tim Dosen, mahasiswa, Kepala Sekolah, serta Guru Pendamping. Sosialisasi ini dilakukan untuk memberikan pengarahan pada Kepala Sekolah dan Guru Pendamping mengenai kegiatan pelatihan dan pendampingan Desain Grafis.

Pelatihan desain grafis dilakukan dalam 1 hari, yang berisi penjelasan materi Corel Draw serta Adobe Photoshop oleh tim pengabdian dan tiga guru pendamping dari guru IT SMK Muhammadiyah 9 Wagir sebagai bentuk partisipasi mitra dalam program. Sasaran pelatihan adalah siswa Jurusan Tata Boga serta
Jurusan Teknik Komputer dan Jaringan. Pelatihan akan difasilitasi dengan sertifikat dan handout untuk siswa dan guru pendamping.

Pendampingan pembuatan label dilaksanakan sebanyak 1 kali setiap minggu dalam kurun waktu 1 bulan. Luaran dari kegiatan ini adalah siswa dapat membuat label produk wirausaha dengan menggunakan Corel Draw atau Adobe Photoshop, serta memperbanyak label dan brosur tersebut sesuai dengan kebutuhan wirausaha mereka.

Kegiatan terakhir adalah evaluasi kegiatan. Evaluasi dilakukan secara keseluruhan dengan melibatkan semua unsur terkait. Evaluasi dilakukan setiap pertemuan dalam bentuk refleksi kegiatan dan evaluasi besar dilaksanakan di akhir setelah semua kegiatan terlaksana. Tujuan kegiatan evaluasi ini untuk mengetahui kendala dalam pelaksanaan kegiatan serta untuk menentukan tindak lanjut yang dilakukan tim agar kegiatan tercapai sesuai dengan target capaian.

\section{HASIL DAN PEMBAHASAN}

Berdasarkan metode yang telah dipaparkan, kegiatan pendampingan dan pelatihan desain grafis untuk kewirausahaan bagi siswa SMK Muhammadiyah 9 Wagir ini dimulai dengan kegiatan persiapan dan sosialisasi. Kegiatan ini kemudian dilanjutkan dengan kegiatan pelatihan desain grafis, dan pendampingan pembuatan label dan brosur.

Hasil kegiatan persiapan adalah diperoleh informasi terkait kondisi kegiatan kewirusahaan yang ada di SMK Muhammadiyah 9 Wagir sebagai luaran dari kegiatan prakarya. Beberapa produk yang telah dihasilkan oleh siswa SMK Muhammadiyah 9 Wagir dari kegiatan kewirausahaan ini diantaranya adalah lalapan ayam goreng, mie ayam, dan keripik singkong. Dalam kegiatan kewirausahaan ini terdapat tiga tahapan yang dilakukan yaitu pra produksi, produksi kemudian pemasaran. Pemasaran merupakan salah satu hal yang penting untuk diperhatikan karena berpengaruh secara langsung pada konsumen [6]. Dalam pelaksanaannya, siswa terkendala pada proses pelabelan produk. Pelabelan yang dilakukan selama ini adalah pelabelan sederhana dengan menggunakan aplikasi Microsoft Word atau sekedar mengambil gambar dari internet. Hasil diskusi dengan pihak sekolah, satu solusi untuk menyelesaikan kendala ini adalah dengan memberikan pelatihan desain grafis yang fokus pada pembuatan pelabelan produk seperti pamflet promosi dan label produk. Pelabelan produk dianggap penting daam berwirausaha. Hal ini didukung berbagai pendapat pada pengabdian dan penelitian terdahulu [7], [8].

Sebelum melakukan sosialisasi program, tim merancang kegiatan pelatihan. Pelatihan diadakan selama tiga hari berturut-turut dengan siswa sebanyak sembilan orang yang terdiri dari siswa kelas 10, 11, dan 12. Aplikasi yang digunakan untuk mendesain adalah Corel Draw karena aplikasi ini mudah dan praktis digunakan. Dalam pelatihan ini juga disisipi materi 
tentang filosofi logo. Selain itu inisiasi untuk peresmian produk melalui BPOM juga menjadi salah satu materi pelengkap dalam pelatihan[9].

Tahap selanjutnya adalah melakukan kegiatan sosialisasi terkait rancangan kegiatan yang akan dilakukan oleh tim dan teknis pelaksanaan program pelatihan desain grafis. Hal ini bertujuan untuk menyesuaikan jadwal yang telah dirancang dengan kegiatan sekolah. Hasil dari kegiatan ini adalah kesepakatan bahwa pelatihan diadakan secara luring dengan penyelenggaraannya bulan September 2020. Koordinasi dan sosialisasi diterima oleh Wakil Kepala Sekolah dan Ketua Jurusan Rekayasa Perangkat Lunak pada tanggal Sabtu, 21 Agustus 2020. Gambar 1 merupakan dokumentasi kegiatan sosialisasi di SMK Muhammadiyah 9 Wagir.

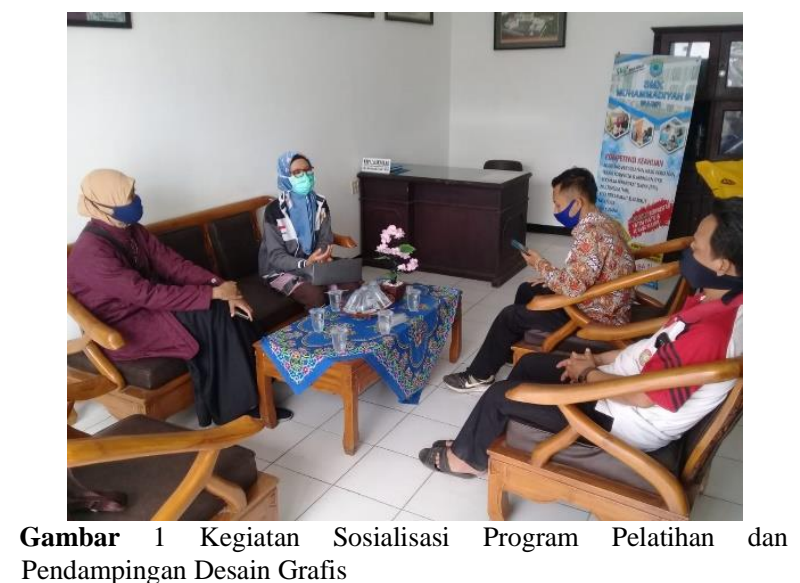

Setelah tahap sosialisasi, tahapan selanjutnya adalah pelatihan desain grafis. Pelatihan dilakukan secara luring di SMK Muhammadiyah 9 Wagir. Pelatihan desain grafis dilakukan pada bulan September, dengan banyak pertemuan 1 kali. Sasaran pelatihan ini adalah siswa kelas X, jurusan Rekayasa Perangkat Lunak terdiri dari 6 siswa. Tujuan pelatihan ini adalah memaparkan pentingnya kewirausahaan bagi siswa SMK, desain grafis sebagai penunjang kegiatan wirausaha di SMK, labeling dan pembuatan leaflet, serta inisiasi pemasaran produk unggul milik SMK Muhammadiyah 9 Wagir dan pengurusan No. IRT produk. Gambar 2 berikut merupakan dokumentasi pelatihan di SMK Muhammadiyah 9 Wagir.

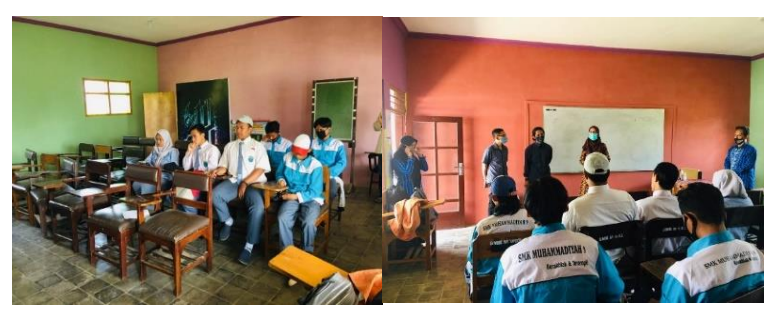

Gambar 2. Kegiatan Pelatihan Desain Grafis
Tahap selanjutnya adalah pendampingan dan workshop pembuatan label dan leaflet. Pendampingan dilakukan sebanyak 3 kali tatap muka, bertempat di laboratorium komputer SMK Muhammadiyah 9 Wagir. Kegiatan workshop adalah pembuatan label dan leaflet untuk produk siswa yang dikembangkan di sekolah. Pembuatan label dan leaflet menggunakan software Corel Draw X5 Portable. Corel Draw dianggap software yang sesuai dalam mendesain label dan pamflet karena kemudahan dan fleksibilitasnya[10]. Terdapat beberapa kendala ketika pendampingan dilaksanakan yaitu belum adanya software Corel Draw pada komputer siswa, walaupun hal tersebut sebelumnya telah dikomunikasikan pada pihak sekolah. Solusi dari permasalahan ini, adalah dengan menggunakan Corel Draw X5 Portable, namun tidak semua komputer support dengan aplikasi ini. Pada akhirnya, secara garis besar, kegiatan pendampingan dapat berjalan dengan lancar. Dan luaran yang diharapkan dari pelatihan dan pendampingan ini dapat tercapai sesuai rencana. Berikut merupakan dokumentasi dan hasil desain label dan leaflet siswa.

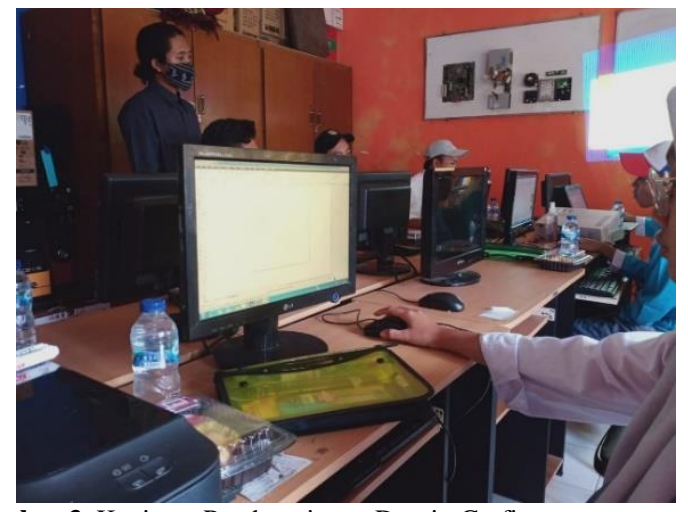

Gambar 3. Kegiatan Pendampingan Desain Grafis

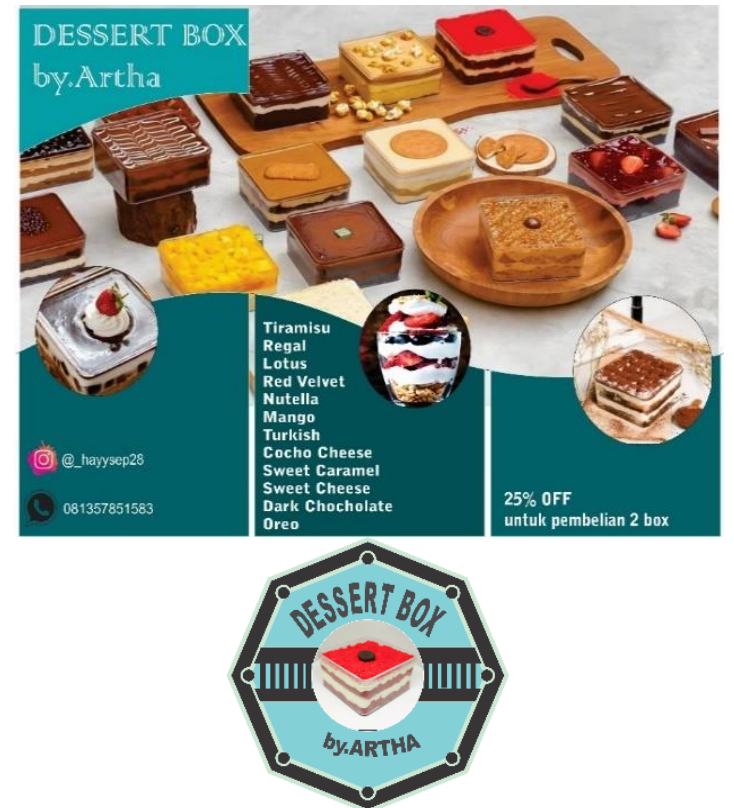

Gambar 4. Hasil Kegiatan Pendampingan Desain Grafis 
Kegiatan pengabdian diakhiri dengan evaluasi terhadap kegiatan pendampingan yang telah dilaksanakan. Pada evaluasi pertama adanya kendala terkait beberapa Personal Computer (PC) yang tidak dapat digunakan. Hal ini dapat diatasi dengan membagi siswa dalam kelompok kerja. Pada pertemuan kedua dan ketiga tidak ada kendala secara teknis. Secara keseluruhan berdasarkan hasil evaluasi akhir, pelatihan pendampingan desain grafis ini bermanfaat terhadap pengembangan kegiatan kewirausahaan siswa SMK Muhammadiyah 9 Wagir.

Evaluasi juga dilakukan dengan beberapa tes pasar skala kecil. Dimana siswa SMK Muhammadiyah 9 Wagir menjual produk dengan dan tanpa label. Kemudian didapat beberapa tanggapan dari konsumen yang menyatakan bahwa pemberian label membuat tampilan produk menjadi lebih cantik dan mudah dikenali variannya.

\section{KESIMPULAN}

Pengabdian berupa pelatihan dan pendampingan desian grafis bagi siswa terlaksana lancar. Hal ini terlihat dari konsistensi banyaknya siswa yang mengikuti pelatihan dan pendampingan selama tiga hari. Selain itu terdapat tanggapan positif dari guru serta siswa yang berdampak pada berhasilnya pelatihan dan pendampingan desain grafis ini. Desain siswa terlihat menarik dan eye catching.

\section{UCAPAN TERIMA KASIH}

Penulis mengucapkan terimakasih kepada institusi, Universitas Muhammadiyah Malang, yang telah memberikan dukungan pendanaan selama berlangsungnya pengabdian masyarakat ini, SMK Muhammadiyah 9 Wagir, atas kesempatan mengaplikasikan ilmu yang diberikan kepada tim pengabdian.

\section{DAFTAR PUSTAKA}

[1] E. Mulyani, "Model Pendidikan Kewirausahaan di Pendidikan Dasar dan Menengah,” J. Ekon. dan Pendidik., 2012.
[2] B. Lastariwati, "Pentingnya Kelas Kewirausahaan pada SMK Pariwisata," J. Pendidik. Vokasi, vol. 2, no. 1, pp. 71-80, 2013. [3] R. Maulida, J. Widodo, and Sunarto, "Peran SMK Mart Dalam Penanaman Sikap Kewirausahaan Pada Siswa (Studi Kasus Di SMK Negeri 1 Kendal)," J. Econ. Educ., vol. 6, no. 1 , pp. 75-81, 2017.

[4] H. Usman and N. E. Raharjo, "Model Pendidikan Karakter Kewirausahaan," J. Pendidik. Teknol. dan Kejuru., vol. 21, no. 2, pp. 140-147, 2012.

[5] M. Wibowo, "Pembelajaran Kewirausahaan dan Minat Wirausaha Lulusan SMK," Ekplanasi, vol. 6, no. September, pp. 109-122, 2011.

[6] Y. Chrismardani, "Komunikasi Pemasaran Terpadu: Implementasi Untuk UMKM," $J$. $\mathrm{NeO}$-Bis, vol. 8, no. 2, 2014.

[7] G. Herydiansyah, "Penyuluhan Pentingnya Label Pada Kemasan Produk Dan Pajak Pada Usaha Kecil Menengah (UKM) Desa Tebedak Ii Kecamatan Payaraman Ogan Ilir," J. Ilm. Pengabdi. Kpd. Masy., vol. 53, no. 9, pp. 16891699, 1970.

[8] V. C. Devi, A. Sartono, and J. T. Isworo, "Hubungan Antara Karakteristik Individu Dan Pengetahuan Label Gizi Dengan Membaca Label Gizi Produk Pangan Kemasan Pada Konsumen Di 9 Supermarket Wilayah Kota Tangerang Selatan Tahun 2016," J. Gizi, vol. 2, no. 2, pp. 1-12, 2013.

[9] A. Hanif, "Implementasi Peraturan BPOM Nomor Hk.03.1.23.04.12.2205 Tahun 2012 Tentang Pedoman Pemberian Sertifikat Produksi Pangan Industri Rumah Tangga (PIrt) Di Kabupaten Pemalang," Universitas Negeri Semarang, 2017.

[10] N. Aini, "Peluang Usaha Dalam Bisnis Distro Dengan Memanfaatkan Keterampilan Coreldraw," Teknol. dan Kejuru., vol. 32, no. 2, pp. 209-218, 2012. 